\title{
OPTIMATION STUDY OF CARRAGEENAN EXTRACTION \\ FROM RED ALGAE (Eucheuma cottonii)
}

\author{
Refilda $^{1^{*}}$, Edison Munaf ${ }^{1}$, Rahmiana Zein $^{1}$, Abdi Dharma ${ }^{1}$, Indrawati ${ }^{1}$ \\ Lee Wah Lim $^{2}$ and Toyohide Takeuchi' \\ ${ }^{1}$ Department of Chemistry, Faculty of Mathematics and Natural Sciences Andalas University \\ ${ }^{2}$ Department of Chemistry, Faculty of Engineering, Gifu University \\ *Corresponding author: telp +6281-26-628-806 \\ email address: refilda_59@yahoo.com
}

\begin{abstract}
Carrageenan is a general name for polysacharides, it is made up of sodium, potassium, magnesium, and calcium sulphat esters of galactose and 3.6-anhydrogalactose units. Research about parameters influencing extraction process of carrageenan from red algae (Eucheuma cottonii) has been studied. The parameters were particle size of red algae, $\mathrm{pH}$ of $\mathrm{NaOH}$ solution, heating time and heating temperature. About $64.30 \%$ of carrageenan was extracted from red algae (Eucheuma cottonii) under optimum condition, $425 \mu \mathrm{m}$ particle size of red algae, solution $\mathrm{pH} 8.5$, heating time $18 \mathrm{~h}$, and heating temperature $95^{\circ} \mathrm{C}$. The FTIR spectra of extracted carrageenan showed the same spectra as the pure carrageenan.
\end{abstract}

Keywords : carrageenan, red algae (Eucheuma cottonii), and extraction

\section{REFERENCES}

1. R. B. William, Post Harvest treatment and Quality Control of Eucheuma Seaweeds, Proceedings of the regional workshop on seaweed culture, 2/18/2007, (2007)

2. FAO, Training Manual on Gracilaria Culture and Seaweed Processing in China, $2 / 6 / 2007$

3. C. Brian, Seaweed Farming: An Alternative Livehood for Small-scale Fishers, Coastal Resources Center, University of Rhode Island, 2002.

4. Syamsuar, Karakteristik Karaginan Rumput Laut (Eucheuma cottonii) pada Berbagai Umur Panen, Konsentrasi,KOH dan Lama Ekstraksi, thesis, Sekolah Pasca Sarjana IPB, 2006.

5. E. W. Julian, N. W. Hira, The Growth of seaweed Commudity in Indonesia, 2006.

6. L. David, Potencial for Eucheuma cottonii Seaweed Farming in Semoa, Food and Agriculture organization of The United Nations, 1999.

7. J. M. Dennis, Prospect for Eucheuma Marketing in The World and The Future of Seaweed Farming in Pacific, dept of chemistry, University of New South Wales, Campbell, Australia, 2007 .

8. Benford, Safety evaluation of Certain Food Additives and Contaminants. Carrageenan and Processed Eucheuma Seaweed (addendum), 2007.

9. A. Kelco, Carrageenan. Denmark. http://www.cPKelco.com. 2004 (16-09-2006)

10. J. Minghou, Processing and Extraction of Phycocoloids, FAO, Corporate Document Repository, 2007.

11. S. Otles, Methods of Analysis of Food Components and Additives, Taylor \&Francis Group, LLC, 2005.

12. FAO, Seaweeds Used as A Source of carrageenan, Fisheries department, 4/20/2007. 
13. MS. Doty, The Production and Use of Eucheuma, Department of Botany, University of Hawaii 2/18/2007.

14. MS. Doty, Eucheuma alvarezii sp.nov (Gigartinales, Rhodophyta) from Malaysia in Abbot IA, Norris JN (editors). Taxonomy of Economic Seaweeds California Sea Grant College Program. $1985,37-45$.

15. F. U. Sandra, J. E. Allan, M. F. Mohammed, B. K. Richard and T. C. Gregory, Carbohydrate Research, 340: 1357-1364, (2005).

16. J. M. Estevez, M Ciancia and AS Cerezo, Carbohydrate Research, 339: 2575.- 2592, (2004).

17. M. L. Liao, A. Chiovvitti, S. L. A. Munro, D. J. Craik, G. T. Kraft, A. Bacic, Carbohydrate Research, 296: 237-247, (1996).

18. T. A. Davis, B. Volesky, A. Mucci, Water Res., 37: 4311-4330, (2003).

19. C. Marcela, A. S. Barros, A. Nunes, S. M Rocha, I. Delgadillo, C. Jana, Manuel, Use of FT-IR spectroscopy as a tool for the analysis of polysaccharide Food additives, Carbohydrate Polymers, 51: 383-389, (2003). 